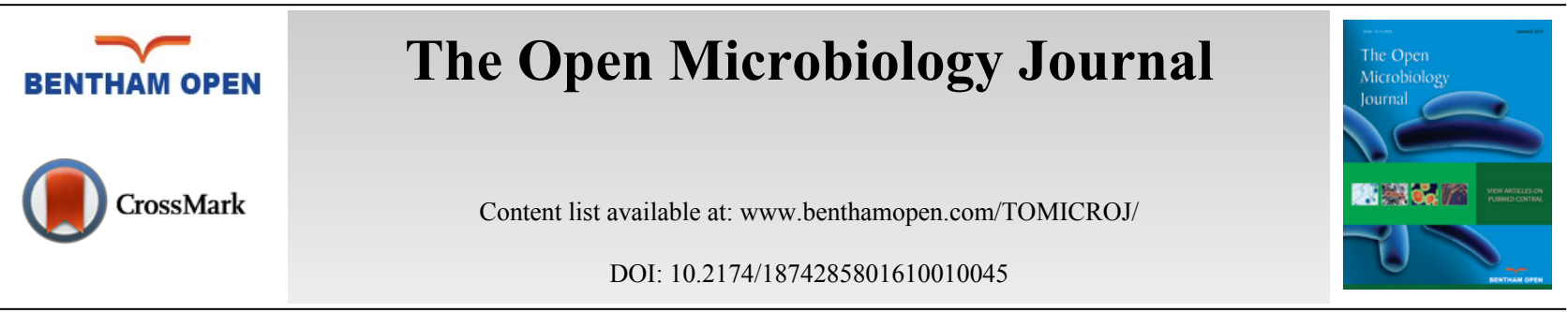

\title{
PCR-based Approaches for the Detection of Clinical Methicillin- resistant Staphylococcus aureus
}

\author{
Ying Liu ${ }^{1,2}$, Jiang Zhang ${ }^{1}$ and Yinduo $\mathrm{Ji}^{2, *}$ \\ ${ }^{1}$ Shanghai Vocational College of Agriculture and Forestry, Shanghai, China \\ ${ }^{2}$ Department of Veterinary Biomedical Science, College of Veterinary Medicine, University of Minnesota, Saint Paul, \\ United States
}

\begin{abstract}
Staphylococcus aureus is an important pathogen that can cause a variety of infections, including superficial and systematic infections, in humans and animals. The persistent emergence of multidrug resistant S. aureus, particularly methicillin-resistant S. aureus, has caused dramatically economic burden and concerns in the public health due to limited options of treatment of MRSA infections. In order to make a correct choice of treatment for physicians and understand the prevalence of MRSA, it is extremely critical to precisely and timely diagnose the pathogen that induces a specific infection of patients and to reveal the antibiotic resistant profile of the pathogen. In this review, we outlined different PCR-based approaches that have been successfully utilized for the rapid detection of $S$. aureus, including MRSA and MSSA, directly from various clinical specimens. The sensitivity and specificity of detections were pointed out. Both advantages and disadvantages of listed approaches were discussed. Importantly, an alternative approach is necessary to further confirm the detection results from the molecular diagnostic assays.
\end{abstract}

Keywords: S. aureus, MRSA, MSSA, diagnosis PCR, multiplex PCR, real-time PCR.

\section{INTRODUCTION}

Staphylococcus aureus is an important human pathogen that can cause a variety of diseases, including skin and soft tissue infections and systematic life threaten infections [1]. The continuing emergence of methicillin resistant $S$. aureus (MRSA), including hospital acquired (HA)-MRSA and community acquired (CA)-MRSA, is a major and increasing threat to public health. Most MRSA isolates are resistant to multiple antibiotics and consequently limit options of antibiotics for effective treatment of the MRSA infections [2].

It has been well established that overuse and misuse antibiotics are key factors that contribute to the spread of drug resistant bacterial pathogens [3]. In order to eliminate this factor, the rapid and correct diagnosis of the pathogen that results in infection is crucial for physicians to choose suitable antibiotics for the treatment bacterial infections. PCRbased approaches that have been successfully utilized for the rapid detection of $S$. aureus, including MRSA and MSSA, directly from various clinical specimens; thus we outline these PCR-based assays in this review.

\section{IDENTIFICATION OF STAPHYLOCOCCUS AUREUS USING PCR}

\subsection{Classic PCR Method to Detect $S$. aureus}

PCR approach has been routinely used to detect $S$. aureus from various samples. Based on a single-base-pair mismatch in the sequence of staphylococcal 16S ribosomal RNA gene, a PCR method was developed to identify S. aureus [4]. Moreover, a chromosomal 442bp DNA fragment specific to $S$. aureus was identified, and it was revealed that this specific $442 \mathrm{bp}$ fragment is ubiquitous in 195 clinical $S$. aureus isolates from patients in a variety of anatomical

\footnotetext{
* Address correspondence to this author at the Department of Veterinary Biomedical Science, College of Veterinary Medicine, University of Minnesota, 1971 Commonwealth Ave. St. Paul, MN 55108, United States; Tel: 612-624-2757; Fax: 612-625-5203; E-mail: jixxx002@umn.edu
} 
sites and geological locations in the world [5]. The conserved $S$. aureus-specific 442bp fragment DNA was sequenced and utilized for detection of $S$. aureus by colony PCR amplification in vitro using the primers, Sa442-1 (5'AATCTTTGTCGGTACACGATATT CACG-3') and Sa442-2 (5'- CGTAATGAGATTTCAGT AGATAATACAACA-3') [5]. PCR buffer containing $50 \mathrm{mM} \mathrm{KCl,} 10 \mathrm{mM}$ Tris- $\mathrm{HCl}$ (pH 9.0), 0.1\% Triton X-100, 2.5 $\mathrm{mM} \mathrm{MgCl}, 0.4 \mathrm{mM}$ (each) the two S. aureus-specific primers, $200 \mathrm{mM}$ (each) the dNPTs, and $0.5 \mathrm{U}$ of Taq DNA polymerase (Promega, Madison, WI) [5]. A portion of colony was mixed in the PCR buffer, and PCR was done at following condition: $3 \mathrm{~min}$ at $96^{\circ} \mathrm{C}, 30$ or 40 cycles of $1 \mathrm{~s}$ at $95^{\circ} \mathrm{C}$ for the denaturation, and $30 \mathrm{~s}$ at $55^{\circ} \mathrm{C}$ for the annealing-extension [5].This PCR assay is simple and rapid; it can be done within $1 \mathrm{~h}$ [5]. This provides a novel diagnostic tool for the diagnosis of $S$. aureus infections. Different target genes for diagnosis PCR may affect the specificity and sensitivity. Using nuc gene (encoding nuclease) as a target for PCR, it was shown 100\% positive rate with as less as $0.69 \mathrm{pg}$ of chromosomal DNA or $10 \mathrm{CFU}$ bacterial cells [6]. Briefly, the bacterial cells wre harvested by centrifugation, lysed in lysis buffer (20 mM Tris- $\mathrm{HCl}$ [pH 8.3], $50 \mathrm{mM} \mathrm{KCl}, 1.5 \mathrm{mM} \mathrm{MgCl}, 0.50 \%$ Tween $20,0.45 \%$ Nonidet P-40, $0.01 \%$ gelatin, and 60 p.g of proteinase $\mathrm{K}$ per $\mathrm{ml}$ ) at $55^{\circ} \mathrm{C}$ for $1 \mathrm{~h}$, then followed by PCR amplification as described [6]. From culture positive blood samples, the nuc nested PCR was able to detect 50 copies or $50 \mathrm{CFU} / \mathrm{ml}$ of blood sample, whereas $10 \mathrm{CFU} / \mathrm{ml}$ of blood sample were enough for detection of $S$. aureus by using the $\operatorname{sodA}$ nested PCR assays [7]. The $S$. aureus genomic DNA was purified using a bacterial genomic DNA kit (Sigma-Aldrich, St. Louis, MO) and utilized as a template DNA for PCR amplification of the nuc and sodA as described [7]. It was demonstrated that the $\operatorname{sod} A$ nested PCR approach is highly specific (specificity $100 \%, 95 \%$ CI $0.92-1$ ) and sensitive (sensitivity $89 \%, 95 \%$ CI $0.75-0.96$ ), and can be utilized to determine whether sepsis is caused by $S$. aureus in two hours using $1 \mathrm{ml}$ of blood sample without the need of culture [7]. Moreover, a $S$. aureus specific 289-bp of vicK gene was revealed and could be utilized to differentiate $S$. aureus from other staphylococcus species by PCR as described [8].

Table 1. PCR identification of methicillin-resistant $S$. aureus (MRSA).

\begin{tabular}{|c|c|c|c|c|c|c|}
\hline Method & Gene & Specimen & Sensitivity & Specificity & Time & Reference \\
\hline PCR & $\begin{array}{l}m e c A \text { and } n u c \\
\text { saul-hsdS1 }\end{array}$ & $\begin{array}{l}\text { clinical swabs } \\
\text { isolates }\end{array}$ & $100 \%$ & $97 \%-100 \%$ & $48 \mathrm{~h}$ & {$[10,14]$} \\
\hline Thermo stabilized PCR & mec $A$, fem $A, 16 S r R N A$, lukS & Nasal swabs & $100 \%$ & $100 \%$ & same-day results & {$[15]$} \\
\hline GenomEra $^{\mathrm{TM}}$ MRSA/SA & $\begin{array}{l}m e c A ; \text { conserved genomic } S . \\
\text { aureus sequence (SA) }\end{array}$ & blood culture & $100 \%$ & $99.8 \%$ & within $1 \mathrm{~h}$ & {$[63]$} \\
\hline $\begin{array}{c}\text { gold nanoparticles (Au NPs) for direct } \\
\text { colouri metric PCR }\end{array}$ & $23 S r R N A$ and $m e c A$ & clinical specimens & $97.14 \%$ & $91.89 \%$ & NA & {$[75]$} \\
\hline $\begin{array}{c}\text { Isothermal signal-mediated amplification } \\
\text { of RNA(CytAMP) }\end{array}$ & coa and mecA & clinical isolates & $100 \%$ & $100 \%$ & $3.5 \mathrm{~h}$ & {$[22]$} \\
\hline
\end{tabular}

\subsection{PCR Identification of Methicillin-resistant $S$. aureus (MRSA)}

Due to the emergence of MRSA, a series of PCR approaches have been developed for identification of MRSA (Table 1). It is well established that the femA gene exists in S. aureus, including MRSA and MSSA, but is absent in coagulase-negative staphylococcus (CNS) strains. On the other hand the mecA gene (encoding high-level methicillin resistance) is present in both MRSA and methicillin-resistant CNS. Therefore, both the fem $A$ and $m e c A$ genes have been successfully used for detection of MRSA [9]. PCR of both mecA and nuc genes from specimens was used for diagnosis of MRSA infections with $97 \%$ specificity and $100 \%$ sensitive and shortened the turnaround time to 48 hours [10]. This method is routinely utilized in clinical laboratories for detecting MRSA in surveillance samples [10]. The colonies were picked and suspended in $0.5 \mathrm{~N} \mathrm{NaCl}$ and used as template DNA for PCR using the mecA and nuc specific primers as described [10]. A PCR-based dipstick assay was developed for direct detection of MRSA from clinical swab specimens. The sensitivity and specificity of this approach reached $94.1 \%$ and $98.3 \%$, respectively, with a lower cost [11]. Moreover, based on the sequence linking the right junction of the SCCmec elements and the adjacent chromosomal region, a PCR method was developed to detect MRSA with 100\% specificity using a forward primer specific targeting the SCCmec element and a reverse primer specific targeting the $\operatorname{orf} X$ region [12]. The genomic DNA was purified from the lysostaphin treated staphylococcal cells, and $10 \mathrm{ng}$ of gDNA was used as a template for PCR in $25 \mu 1$ PCR mixture (2.5 pmol of each primer and $200 \mu \mathrm{M}$ each dNTP, $10 \mathrm{mM}$ Tris- $\mathrm{HCl}, \mathrm{pH} 9.0,1.5 \mathrm{mM} \mathrm{MgCl}_{2}, 500 \mathrm{mM} \mathrm{KCl}$ and $1.3 \mathrm{U}$ of rTaq DNA polymerase) in a thermocyclyer as described [12]. The recent emergence of community-acquired (CA)MRSA has caused a serious public concern. It is important to develop a robust tool to detect CA-MRSA. It has been found that the $p b p 3$ gene is specifically present in the CA-MRSA isolates. A single allele-specific PCR targeting the G88A polymorphism has been developed using purified genomic DNA as a template and CaMRSA-For-AA or CaMRSA-For-AG and CaMRSA-Rev-4 primers [13]. This approach could effectively be utilized to detect USA300- 
MRSA with $100 \%$ sensitive and specificity as well as CA-MRSA with $91.5 \%$ sensitive and $100 \%$ specificity [13]. MRSA complex clone, CC398, is an important zoonotic agent due to its prevalence in livestock. Based on the Sau1HsdS1 lineage-specific type I restriction-modification system, a PCR method has been developed to detect MRSA CC398 in both hospitals and on farms [14]. Recently, a dry reagent-based thermostabilized PCR has been established for the detection of MRSA through simultaneous amplification of 16s rRNA, femA, mecA and $l u k S$ genes with 100\% sensitivity and specificity [15]. The bacterial cells was lysed by boiling and used as a template for PCR amplification using thermostabilized PCR reagents [15]. Moreover, it was determined that the limitation of detection is $10^{6} \mathrm{CFU}$ and $10 \mathrm{ng}$ of genomic DNA using this approach, which is similar to conventional PCR [15].

\section{DETECTION OF MRSA USING MULTIPLEX PCR}

\subsection{Multiplex PCR for Identification of MRSA}

To enhance the specificity and efficiency of detecting MRSA, a variety of multiplex PCR has been developed based on different S. aureus specific target genes (Table 2). Two pairs of primers specific to staphylococcal nuc and mecA, respectively, were designed and utilized for multiplex PCR using purified genomic DNA as a template for PCR amplification of a $280 \mathrm{bp} \mathrm{nuc} \mathrm{based} \mathrm{fragment} \mathrm{and} \mathrm{a} 533 \mathrm{bp} \mathrm{mecA}$ based fragment [16]. It was revealed that the multiplex amplification of $n u c$ is $100 \%$ specific compared with the detection of coagulase production; moreover, more that $96.8 \%$ to $97.7 \%$ specificity could be achieved for detecting MRSA by multiplex amplifying mecA compared with in vitro oxacillin susceptibility assays [17]. The multiplex amplification of femA or femB (fragment specific for S. aureus) and $m e c A$ fragments has been successfully used for the identification of MRSA isolates from patient samples [18 - 20]. The specimens were homogenized in TE buffer ( $20 \mathrm{mM}$ Tris $\mathrm{HCl}$ [pH8.0], $10 \mathrm{mM}$ EDTA) with 2\% SDS; the bacterial cells were harvested from homogenate by centrifugation, lysed with TE buffer containing $1 \%$ Triton X-100 and $50 \mu \mathrm{g}$ lysostaphin. The lysis was further treated with proteinase $\mathrm{K}$ and followed by bacterial DNA purification, which was subjected to multiplex PCR [18]. Recently, a multiplex PCR approach was developed for the differentiation of MRSA and methicillin- resistant coagulase negative Staphylococcus (MR-CNS) isolates from burn patients by colony PCR amplification of $16 \mathrm{~S}$ rRNA, mecA, and $n u c$ gene fragments [21]. A mecA homologue, $m e c C$, has been identified and possesses $70 \%$ identity with $m e c A$ at the DNA level [22], and a $m e c C$-based multiplex PCR was utilized for the identification of MRSA and the detection of $m e c A$ and $m e c C$ genes using extracted DNA as a template [23].

Table 2. Multiplex PCR for the identification and characterization of MRSA.

\begin{tabular}{|c|c|c|c|c|c|c|}
\hline Method & Gene & Specimen & Sensitivity & Specificity & Time & Reference \\
\hline multiplex PCR-immunoassay & $m e c A$ and $f e m B$ & screening swabs & NA & NA & $24 \mathrm{~h}$ & [76] \\
\hline Multiplex PCR & $\begin{array}{c}\text { 280-bp nuc-based fragment,533-bp mecA- } \\
\text { based fragment, mecA, mecC, femB,16S } \\
r R N A, \text { nuc }\end{array}$ & isolates & $100 \%$ & $98 \%-100 \%$ & $3 h, 5 h$ & $\begin{array}{c}{[16,23,19,21,} \\
77]\end{array}$ \\
\hline Quadriplex PCR & $16 S r R N A, n u c$, mecA and mupA & isolates & $100 \%$ & $100 \%$ & NA & {$[25]$} \\
\hline multiplex PCR & femA and $m e c A$ & endotracheal aspirates & NA & NA & $>6 \mathrm{~h}$ & [18] \\
\hline multiplex PCR & $\begin{array}{l}\text { S. aureus species-specific and mecA gene } \\
\text { segments }\end{array}$ & Nasal swabs & $96.5 \%$ & $100 \%$ & $\begin{array}{c}\text { within } \\
24 \mathrm{~h}\end{array}$ & [78] \\
\hline triplex qPCR & mec $A$, fem $A$ & clinical swabs & $100 \%$ & $64 \%$ & $>6 \mathrm{~h}$ & {$[20]$} \\
\hline
\end{tabular}

\subsection{Multiplex PCR for Characterization of MRSA}

The multiplex colony PCR amplification of the 310, 456, and 651-bp fragments of mecA, ileS-2, (encoding highlevel mupirocin resistance), and $f e m B$, respectively, was able to identify multidrug resistant MRSA from a single colony [24]. In order to discriminate MRSA, MR-CoNS, and mupirocin-resistant staphylococci, a quadriplex PCR was established with $100 \%$ sensitivity, specificity, and accuracy by targeting 16S rRNA (staphylococcus genus specific), nuc (S. aureus specific), mecA and тирA (mupirocin resistant gene) gene fragments [25]. The genomic DNA was extracted from bacterial colonies and used as a template for amplification following the PCR condition as described [25]. A multiplex PCR approach targeting of $m e c A$ and $p v l$ (encoding Panton-Valentine Leukocidin) allows us to identify both USA300 and USA400 CA-MRSA isolates [26]. Thus, the quadriplex PCR of S. aureus 16S rRNA, nuc, тесA and тир $A$ genes enables us to simultaneously identify a mupirocin resistant MRSA, while the multiplex PCR of $m e c A$ and $p v l$ genes allows us to distinguish prevalent USA300 and USA400 CA-MRSA. Based on a unique more than 6 AT repeats signature and $p v l$ gene in USA300 chromosomal DNA, a multiplex PCR assay was developed using genomic DNA as a template for PCR amplification that can be utilized to directly identify USA300 MRSA strains [27]. 
Moreover, using bacterial lysates as template and optimized concentration of primer for each gene and PCR condition, a pentaplex PCR was developed for rapid identification and characterization of MRSA isolates by simultaneous PCR amplification of 16S rRNA gene, femA, mecA, lukS (encoding Panton-Valentine leukocidin, PVL), and an internal control gene fragments [28]. Using a similar strategy, a multiplex PCR for 16S rRNA, nuc, mecA, pvl, czrC (cadmium/zinc) and $q a c A / B$ (encoding antiseptic resistance) gene fragments was utilized to identify and characterize MRSA, PVL-positive and negative $S$. aureus, as well as discriminate CNS from the ocular samples [29]. The above studies demonstrated that the multiplex PCR provides a rapid and reliable approach to identify and characterize MRSA isolates. The sensitivity, specificity, and efficiency of different multiplex PCR assays for identification and characterization of MRSA were compared and outlined in Table 2.

Table 3. Identification of $S$. aureus, including MRSA, using Real-Time PCR.

\begin{tabular}{|c|c|c|c|c|c|c|c|}
\hline Method & Gene & Genus & Specimen & Sensitivity & Specificity & Time & Reference \\
\hline single-locus real time PCR & $m e c A$ & MRSA & nasal swab & $92.3 \%$ & $98.6 \%$ & $<90 \mathrm{~min}$ & {$[32]$} \\
\hline Taq Man real time PCR & $f n b A$ & S. aureus & $\begin{array}{c}\text { lower respiratory tract } \\
\text { specimens }\end{array}$ & $100 \%$ & $100 \%$ & $2 \mathrm{~h}$ & {$[30]$} \\
\hline $\begin{array}{c}\text { Real time PCR(Roche analyte- } \\
\text { specific reagents) }\end{array}$ & $m e c A$ & S. aureus & nasal swabs & NA & NA & within $3-5 \mathrm{~h}$ & {$[33]$} \\
\hline In house real-time PCR & mecA & S. aureus & nasal swabs & NA & NA & within 3 to $5 \mathrm{~h}$ & \\
\hline Real time PCR & $m e c A$, orf $X$, nuc & MRSA & blood cultures & $100 \%$ & $99.2 \%$ & $2 \mathrm{~h}, 3 \mathrm{~h}$ & {$[37,42]$} \\
\hline Real time PCR & $S C C m e c$, orf $X$ & MRSA & nasal swabs & $100 \%$ & $98.4 \%, 99 \%$ & $<1 \mathrm{~h}$ & {$[34,79]$} \\
\hline Real time PCR & $\begin{array}{c}\text { Nuc, } \\
\text { orf } X\end{array}$ & MRSA & clinical swabs & $93 \%, 93.3 \%$ & $\begin{array}{c}89.6 \%, \\
100 \%\end{array}$ & $<90$ min & {$[35,80]$} \\
\hline Real time PCR & $S C C m e c$ & MRSA & screening swabs & $98.6 \%$ & $99.4 \%$ & $<7 \mathrm{~h}$ & {$[36]$} \\
\hline Real time PCR & orfX & MRSA & clinical isolates & $98 \%$ & $100 \%$ & $<90 \mathrm{~min}$ & {$[35]$} \\
\hline
\end{tabular}

Table 4. Identification of $S$. aureus, including MRSA, using multiplex RT-PCR.

\begin{tabular}{|c|c|c|c|c|c|c|c|}
\hline Method & Gene & Genus & Specimen & Sensitivity & Specificity & Time & Reference \\
\hline $\begin{array}{c}\text { Multiplex real time } \\
\text { PCR }\end{array}$ & $\begin{array}{c}\text { SCCmec/orf } X \text { junction; } l u k F \\
\text { and } l u k S\end{array}$ & MRSA & nasal swabs & $95 \%, 93.5 \%$ & $99 \%, 82.9 \%$ & NA & {$[48,50]$} \\
\hline $\begin{array}{c}\text { Multiplex real time } \\
\text { PCR }\end{array}$ & $\begin{array}{c}\text { various SRE sequences, } \\
\text { orfX(Xsau325), } \\
\text { SCCmec }\end{array}$ & MRSA & clinical specimens & NA & NA & $<1 \mathrm{~h}$ & {$[44,45]$} \\
\hline $\begin{array}{c}\text { Triplex real time PCR } \\
\text { mecA,coa, Sa442 }, \text { femA }\end{array}$ & $\begin{array}{c}\text { S. aureus and } \\
\text { methicillin } \\
\text { resistance }\end{array}$ & Clinical isolates & $100 \%$ & $100 \%$ & $3 \mathrm{~h}$ & {$[43,47]$} \\
\hline Triplex real time PCR & tuf, nuc, and mecA & S. aureus & blood culture & $99.2 \%-100.0 \%$ & $98.7 \%-100.0 \%$ & $90 \mathrm{~min}$ & {$[51]$} \\
\hline $\begin{array}{c}\text { Double triplex real time } \\
\text { PCR }\end{array}$ & $\begin{array}{c}\text { tuf, nuc, mecA, atlE, gap } \text { and } \\
\text { mvaA }\end{array}$ & S.aureus & blood culture & NA & NA & 83 min & {$[52]$} \\
\hline
\end{tabular}

\section{IDENTIFICATION OF S. AUREUS, INCLUDING MRSA, USING REAL-TIME PCR}

Different real-time PCR assays have been established to the identification of $S$. aureus (Table 3). fnbA gene (encoding a fibronectin-binding protein A) was utilized for real-time PCR (RT-PCR) to quantitatively detect $S$. aureus directly from lower respiratory tract samples of the patients [30]. The genomic DNA was purified from bacterial samples and used as a template DNA for real-time PCR as described [30]. However, it is possible to obtain false negative results, as not every $S$. aureus isolate possesses $f n b A$ gene [31]. Based on the fact that the mecA gene is located in the staphylococcal cassette chromosome mec, a MRSA-specific single-locus real-time PCR was developed for rapid detection of MRSA directly from swab samples [32 - 36]. The swab was votexed in $1 \mathrm{ml}$ sample buffer, which was followed by centrifugation. The pellet was lysed in the lysis buffer and used for real-time PCR as described [http://www.geneohm.com, 32]. Using this approach more than $92 \%$ sensitivity and $99 \%$ specificity could be achieved; however, it should be point out that other methods may be needed to confirm the assays, because using IDI-MRSA method 4.7\% swab samples did not yield PCR product and 5.1\% swab samples generated false positive [32]. RT-PCR has been successfully used to detect MRSA directly from blood culture bottles through targeting both $m e c A$ and orf $X$ genes within $2 \mathrm{~h}$ [37]. The bacterial lysis from $1 \mu \mathrm{l}$ of blood culture was used as a template for RT-PCR testing using the Cepheid SmartCycler ${ }^{\circledR}$ system (Cepheid, Sunnyvale, CA) with GeneOhm reagents (GeneOhm Sciences, San Diego, CA). This approach could reach $97 \%$ accuracy for the detection of MRSA directly from the cultured blood samples 
[37 - 39]. IDI-MRSA is a RT-PCR based and qualitatively diagnostic approach for the rapid detection of MRSA directly from nasal swabs (Infectio Diagnostic, Inc., Sainte-Foy, Québec, Canada). This approach could achieve 91.7\% sensitivity and $93.5 \%$ specificity for the diagnosis of MRSA directly from nasal swab specimens [40]. The IDI-MRSA assay can also be used to detect MRSA from pooled and individual samples cultivated in a selective broth medium with $96 \%$ sensitivity and specificity compared to the bacterial culture [41]. Different approaches of genomic DNA extraction from blood culture were compared for RT-PCR detecting MRSA, and the results showed that the benzyl alcohol extraction is more reliable for the real-time amplification of the mecA and nuc genes and the rapid detection of MRSA /MSSA from the positive blood culture samples [42].

\section{IDENTIFICATION OF $S$. AUREUS, INCLUDING MRSA USING MULTIPLEX RT-PCR APPROACHES}

Different multiplex real-time PCR methods have been developed for diagnosis of MRSA from clinical specimens (Table 4). By targeting $m e c A$, ermA, and femA genes, a triplex RT-PCR was developed using TaqMan probes and optimized concentrations of primers for the identification of MRSA from collected $S$. aureus samples within $3 \mathrm{~h}$ [43]. Based on the staphylococcal cassette chromosome mec (SCCmec) and $S$. aureus specific orf $X$ gene sequences, a set of primers specific to SCCmec sequence and three $\operatorname{orf} X$ specific beacon probes were designed and successfully used for rapid multiplex RT-PCR for the identification of MRSA from clinical samples [44]. Either purified genomic DNA or crude DNA extract from bacterial cells could be utilized as a template for amplification. The sensitivity of this approach is high, and it could detect MRSA from a sample with $25 \mathrm{CFU}$ of bacteria. Moreover, it provides a powerful approach to differentiate MRSA from clinical samples with different staphylococci [44, 45]. The specificity could be improved to reduce false positive results by including 16S rRNA gene in the multiplex RT-PCR [46]. Moreover, The specificity of the diagnosis multiplex RT-PCR assay could also be enhanced by simultaneously detecting two $S$. aureus specific DNA sequences including Sa442 DNA sequence and coa gene [47]. Simultaneous amplification of $m e c A, l u k F$ and $l u k S$ genes using RT-PCR was also used to detect MRSA from clinical swab samples with $95 \%$ sensitivity and $99 \%$ specificity [48]. It was revealed that two of the PVL-positive swabs were MRSA and three were MSSA [48]. Moreover, the multiplex RT-PCR amplification of $n u c, m e c A$, $t s t$ and $l u k S-P V$ genes enables to identify MRSA isolates carrying toxic shock syndrome toxin I and/or Panton-Valentine leukocidin gene using the genomic DNA prepared from the clinical samples [49]. It could be utilized to detect MRSA directly from nasal samples based upon the ability of SYBR Green I integrating into six dual priming AT-rich primers as described [50]. This approach could detect $1 \mathrm{pg}$ genomic DNA of MRSA isolates with relatively high sensitivity $(93.5 \%)$ and specificity $(82.9 \%)$ for the identification of MRSA from nasal samples [51]. The tuf gene encodes an essential elongation factor Tu that is specific to Staphylococcus genus; the nuc gene is $S$. aureus specific; the atlE gene (encoding autolysin E) is $S$. epidermidis specific, the gap gene (encoding glyceraldehyde-3-phosphate dehydrogenase) is $S$. hominis specific, mvaA gene (encoding HMG-CoA reductase) is $S$. heamolyticus specific; and the mecA gene encodes methicillin resistance. Thus, the RT-PCR of these genes not only can be utilized to differentiate these species of staphylococci, including coagulase-positive $S$. aureus and coagulase-negative staphylococci, but also can be used to identify methicillin resistant staphylococci, including MSSA and MRCNS. By targeting the $t u f, n u c$ and $m e c A$ genes, a triplex RT-PCR was developed to identify MRSA directly from positive blood culture bottles with more than $99 \%$ sensitivity and specificity [51]. Furthermore, a double triplex RT-PCR was established to detect $t u f$, nuc and $m e c A$ genes in one reaction and atlE, gap and mvaA genes in another reaction tube simultaneously [52]. This multiplex RT-PCR strategy has been successfully used to detect and differentiate $S$. aureus, S. epidermidis, S. hominis, and S. heamolyticus directly from Gram-positive blood culture bottles [52].

\section{IDENTIFICATION OF MRSA USING DIFFERENT AUTOMATED MRSA RT-PCR SYSTEMS}

Due to the demand of rapid diagnosis of MRSA infections in public health sector, various automatic MRSA detection systems have been developed and utilized for high throughput screening of MRSA isolates directly from clinical samples (Table 5). A GeneXpert Dx system has been used for the identification of MRSA using an Xpert MRSA cartridge holding necessary reagents for RT-PCR detection of SCCmec. This system was used to detect MRSAspecific DNA sequence directly from different clinical samples, including transtracheal aspirates and bronchoalveolar fluid, blood cultures, and swabs [53 - 58]. Different sensitivity and specificity have been determined for the detection of MRSA from different clinical samples. For blood culture samples an Xpert MRSA/SA Blood culture assay could achieve a higher specificity (100\%), but low sensitivity (75\%) for the detection of MRSA [54]; for nasal swabs the sensitivity and specificity of MRSA detection were $69.2 \%$ and $97.7 \%$, respectively $[55,59]$. No significant difference of performance exhibited between the Xpert MRSA and BD GeneOhm MRSA assays compared to golden standard culture 
methods [60 - 62]. A GenomEra CDX PCR system was developed for the rapid detection of MRSA from positive blood cultures with higher sensitivity (100\%) and specificity (99.8\%) [63]. Roche Diagnostics has developed a LightCycler MRSA Advanced Test system for RT-PCR detection of MRSA directly from nasal swabs with overall $83.3 \%$ sensitivity and $99 \%$ specificity [64]. It was found that the sensitivity and specificity are similar between the LightCycler MRSA Advanced Teat and the Xpert MRSA assay for detection of MRSA from human swab specimens [65].

Table 5. Identification of MRSA using different automated MRSA RT-PCR systems.

\begin{tabular}{|c|c|c|c|c|c|c|c|}
\hline Method & Gene & Genus & Specimen & Sensitivity & Specificity & Time & Reference \\
\hline ChromID MRSA & mecA & MRSA & Nasal swabs & $100 \%$ & $87.0 \%$ & NA & [84] \\
\hline $\begin{array}{l}\text { BD GeneOhm } \\
\text { (IDI-MRSA) }\end{array}$ & $\begin{array}{c}\text { Junction of SCCmec } \\
\text { and } \operatorname{orf} X\end{array}$ & MRSA & swabs & \begin{tabular}{|l|}
$95.7 \%, 78.7 \%, 84.3 \%$ \\
$93.3 \%, 92 \%, 91.7 \%$ \\
$96 \%, 100 \%$
\end{tabular} & \begin{tabular}{|l}
$91.7 \%, 96.9 \%, 99.2 \%$ \\
$95.2 \%, 98 \%, 93.5 \%$ \\
$96 \%, 98.6 \%$
\end{tabular} & $\begin{array}{c}5-6 \mathrm{~min} \text { per sample, or } \\
1.5 \mathrm{~h}\end{array}$ & \begin{tabular}{|c|}
$40,41,61$ \\
$62,81,82$, \\
$87,90]$
\end{tabular} \\
\hline $\begin{array}{c}\text { real-time PCR } \\
\text { analyte-specific } \\
\text { reagent (ASR) } \\
\text { assay }\end{array}$ & & MRSA & nasal swabs & $100 \%$ & $92 \%$ & $<2$ hours & [85] \\
\hline $\begin{array}{l}\text { the GenomEra }{ }^{\mathrm{TM}} \\
\text { MRSA/SA }\end{array}$ & $\begin{array}{c}\text { mecA and conserved } \\
\text { genomic } S . \text { aureus } \\
\text { sequence (SA) }\end{array}$ & MRSA & blood culture & $100.0 \%$, & $99.8 \%$ & within $1 \mathrm{~h}$ & [63] \\
\hline Xpert MRSA & SCCmec, spa, mесA & MRSA & swabs & $\begin{array}{l}99 \%, 100 \%, 95 \% \\
78.3 \%, 90 \%, 89.3 \% \\
94.3 \% 86.3 \%\end{array}$ & $\begin{array}{l}95.5 \%, 90.7 \%, 97 \%, \\
97.7 \%, 97 \%, 97.9 \% \\
93.2 \% 94.9 \%\end{array}$ & $\begin{array}{c}<1 \mathrm{~h} ; 1.9 \mathrm{~h}-2.6 \mathrm{~h} ; \text { or } \\
2.35 \mathrm{~min} \text { per sample, } \\
\text { PCR cycling time of } \\
\leq 72 \mathrm{~min}\end{array}$ & $\begin{array}{c}{[53,55,56} \\
59,60,65 \\
86]\end{array}$ \\
\hline Xpert MRSA & SCCmec & MRSA & $\begin{array}{c}\mathrm{BC} \\
\text { specimens }\end{array}$ & $75 \%$ & $100 \%$ & $1.5 \mathrm{~h}$ & [54] \\
\hline Xpert MRSA & spa, тесA, SCCmec & MRSA, & $\begin{array}{l}\text { lower } \\
\text { respiratory } \\
\text { tract } \\
\text { secretions }\end{array}$ & $99.0 \%$ & $72.2 \%$ & $<1 \mathrm{~h}$ & [58] \\
\hline Xpert MRSA & $\begin{array}{c}\text { spa, mecA, junction of } \\
\text { SCCmec and orf } X\end{array}$ & MRSA & $\begin{array}{l}\text { Bone and } \\
\text { joint } \\
\text { infection }\end{array}$ & $94.4 \%$ & $100 \%$ & $<1 \mathrm{~h}$ & [57] \\
\hline LightCycler Test & $\begin{array}{c}\text { SCCmec/orfX, mecA, } \\
\text { SCCmecintegration } \\
\text { site }\end{array}$ & MRSA & swabs & $\begin{array}{l}95.7 \%, 88 \%, 83.3 \% \\
95.2 \%, 100 \%, 95.2 \%\end{array}$ & $\begin{array}{l}90.8 \%, 95.9 \%, 99.0 \% \\
95.5 \%, 90.1 \%, 96.4 \%\end{array}$ & $\begin{array}{c}1.40 / 4.74 \mathrm{~min} \text { per } \\
\text { sample }\end{array}$ & $\begin{array}{c}{[64,65,85} \\
89,90]\end{array}$ \\
\hline LightCycler Test & $\begin{array}{c}\text { fragment of } m e c A \text { and } \\
\text { fragment of } \mathrm{Sa} 442\end{array}$ & MRSA & $\begin{array}{l}\text { clinical } \\
\text { isolates }\end{array}$ & NA & NA & within $4 \mathrm{~h}$ & [83] \\
\hline LightCycler Test & mecA & MRSA & blood culture & $100 \%$ & $100 \%$ & NA & [88] \\
\hline $\begin{array}{c}\text { duplex LightCycler } \\
\text { PCR }\end{array}$ & mecA, sa442 & MRSA & \begin{tabular}{|c|} 
clinical \\
isolates and \\
type strains
\end{tabular} & $100 \%$ & $100 \%$ & $70 \mathrm{~min}$ & [91] \\
\hline $\begin{array}{c}\text { real-time } \\
\text { fluorescence PCR } \\
\text { with the } \\
\text { LightCycler device } \\
\end{array}$ & $\begin{array}{l}\text { sa } 442 \text { and a } 98-b p \\
\text { fragment }\end{array}$ & MRSA & $\begin{array}{l}\text { blood } \\
\text { cultures }\end{array}$ & $100 \%$ & $100 \%$ & $2 \mathrm{~h}$ & [39] \\
\hline $\begin{array}{c}\text { IsoAmp } \\
\text { RapidStaph } \\
\text { Detection kit }\end{array}$ & пис, тесA & MRSA & blood culture & $100 \%$ & $100 \%$ & $<1.5 \mathrm{~h}$ & [67] \\
\hline
\end{tabular}

\section{IDENTIFICATION OF S. AUREUS AND MRSA USING ISOTHERMAL AMPLIFICATION APPROACHES}

Although PCR has been successfully used to amplify a specific DNA fragment, it requires a thermocycler and involves many cycles of reactions, including DNA denature, primer annealing, and extension, by changing temperature at different stages of reaction. Recently, the isothermal application technologies have been developed for amplification of DNA fragments; it costs effectively and can be used to rapidly amplify a specific DNA sequence, as it doesn't requires any thermocyclers to change reaction temperature. A helicase-dependent isothermal amplification (HDA) is based on the double-strand DNA unwinding activity of a helicase to separate strands, allowing primer annealing and extension with DNA polymerase [66]. This approach was employed to detect $S$. aureus and MRSA directly from grampositive blood culture medium by targeting the nuc and mecA genes using a disposable device. Both the sensitivity and specificity could reach to $100 \%$ for clinical diagnosis of $S$. aureus and $100 \%$ and $98 \%$ for MRSA detection; the 
detection limitation was $50 \mathrm{CFU} /$ reaction [67]. From the clinical swab samples, the overall relative sensitivity and specificity were $89 \%$ and $94 \%$, respectively, for detection of S. aureus using the HDA-based assay [68]. A loopmediated isothermal amplification (LAMP) uses 4-6 primers that recognizing 6-8 different regions of target DNA. A strand-displacing DNA polymerase with two primers initiates DNA synthesis and forms two loop structures to facilitate subsequent amplification of target DNA [69]. A LAMP-based approach was employed to rapidly and directly detect MRSA in blood cultures by isothermal amplification of spa and mecA genes at $63^{\circ} \mathrm{C}$. The diagnostic values of LAMP could reach to $92.3 \%$ sensitivity, $100 \%$ specificity, $100 \%$ positive predictive value, and $96.9 \%$ negative predictive value [70]. The results of LAMP were consistent with those of a duplex RT-PCR assay, but the LAMP-based detection is cost-effective [70, 71]. The LAMP-based technology has been explored to detect and differentiate $S$. aureus, including MRSA/MSSA, and to determine antibiotic resistant profiles of $S$. aureus from different samples by targeting $s p a / m e c A$, $n u c / m e c A, \operatorname{orf} X$, femA, femB/mecA/qacA/B [70 - 74].

The comparison of sensitivity and specificity among various isothermal amplification methods for detection of S. aureus and/or MRSA is listed in Table 6.

\section{CONCLUSION}

Although different PCR-based molecular diagnostic technologies, including end-point PCR, real-time PCR, multiplex PCR, and isothermal amplification of specific target DNA sequence, have been successfully established and utilized for rapid detection of $S$. aureus, including MRSA and MSSA, directly from various clinical specimens, alternative approaches such as traditional golden standard culture method are necessary to further confirm the results due to false positive and false negative results. Targeting different genes and different PCR approaches can give distinct sensitivity and specificity. Thus, it is important to design reasonable strategy for rapid screening of MRSA directly from clinical samples. The recently developed isothermal amplification techniques provide a more convenient and costeffective strategy for the rapid identification of $S$. aureus.

Table 6. Identification of $S$. aureus, including MRSA, using isothermal amplification.

\begin{tabular}{|c|c|c|c|c|c|c|c|}
\hline Method & Gene & Genus & Specimen & Sensitivity & Specificity & Time & Reference \\
\hline Loop-mediated isothermal amplification & spa, mecA & MRSA & Blood cultures & $92.3 \%$ & $100 \%$ & $2 \mathrm{~h}$ & [70] \\
\hline Loop-mediated isothermal amplification & nuc, mec $A$, orf $X$ & \begin{tabular}{|c|} 
S. aureus \\
MRSA
\end{tabular} & Strains and isolates & $98.4 \%$ & $100 \%$ & $60 \mathrm{~min}$ & {$[71,72]$} \\
\hline Loop-mediated isothermal amplification & $\operatorname{fem} A, \operatorname{arc} C$ & \begin{tabular}{|l|} 
MRSA, \\
S. aureus
\end{tabular} & Clinical samples & $96.9 \%, 100 \%$ & $100 \%$ & $80 \mathrm{~min}$ & {$[73,92]$} \\
\hline $\begin{array}{c}\text { Isothermal signal-mediated amplification of } \\
\text { RNA(CytAMP) }\end{array}$ & $\operatorname{coa}$ and $m e c A$ & MRSA & Clinical isolates & $100 \%$ & $100 \%$ & $3.5 \mathrm{~h}$ & [93] \\
\hline 3 Loop-mediated isothermal amplification & femB, mecA & MRSA & Isolates & NA & $100 \%$ & NA & {$[74]$} \\
\hline
\end{tabular}

\section{CONFLICT OF INTEREST}

The authors confirm that this article content has no conflict of interest.

\section{ACKNOWLEDGEMENTS}

This work was partially funded by Shanghai Vocational College of A\&F scholarship (Ying Liu), AES Hatch Formula Funds MIN-63-082 (Yinduo Ji) and NIH grant AI078951 (Yinduo Ji).

\section{REFERENCES}

[1] Talan DA, Krishnadasan A, Gorwitz RJ, et al. Comparison of Staphylococcus aureus from skin and soft-tissue infections in US emergency department patients, 2004 and 2008. Clin Infect Dis 2011; 53(2): 144-9. [http://dx.doi.org/10.1093/cid/cir308] [PMID: 21690621]

[2] Gleghorn K, Grimshaw E, Kelly EK. New antibiotics in the management of acute bacterial skin and skin structure infections. Skin Ther Lett 2015; 20(5): 7-9.

[PMID: 26382907]

[3] Rodríguez-Baño J, Alcalá JC, Cisneros JM, et al. Community infections caused by extended-spectrum beta-lactamase-producing Escherichia coli. Arch Intern Med 2008; 168(17): 1897-902.

[http://dx.doi.org/10.1001/archinte.168.17.1897] [PMID: 18809817]

[4] Saruta K, Hoshina S, Machida K. Genetic identification of Staphylococcus aureus by polymerase chain reaction using single-base-pair mismatch in 16S ribosomal RNA gene. Microbiol Immunol 1995; 39(11): 839-44.

[http://dx.doi.org/10.1111/j.1348-0421.1995.tb03280.x] [PMID: 8657010] 
[5] Martineau F, Picard FJ, Roy PH, Ouellette M, Bergeron MG. Species-specific and ubiquitous-DNA-based assays for rapid identification of Staphylococcus aureus. J Clin Microbiol 1998; 36(3): 618-23.

[PMID: 9508283]

[6] Brakstad OG, Aasbakk K, Maeland JA. Detection of Staphylococcus aureus by polymerase chain reaction amplification of the nuc gene. J Clin Microbiol 1992; 30(7): 1654-60.

[PMID: 1629319]

[7] Banada PP, Chakravorty S, Shah D, Burday M, Mazzella FM, Alland D. Highly sensitive detection of Staphylococcus aureus directly from patient blood. PLoS One 2012; 7(2): e31126.

[http://dx.doi.org/10.1371/journal.pone.0031126] [PMID: 22363564]

[8] Liu ZM, Shi XM, Pan F. Species-specific diagnostic marker for rapid identification of Staphylococcus aureus. Diagn Microbiol Infect Dis 2007; 59(4): 379-82.

[http://dx.doi.org/10.1016/j.diagmicrobio.2007.06.011] [PMID: 17911002]

[9] Oshima T, Miyachi H, Fusegawa H, Masukawa A, Ikeda M, Ando Y. Detection of methicillin-resistant Staphylococcus aureus by in vitro enzymatic amplification of $m e c A$ and $f e m A$ genes. Rinsho Byori 1993; 41(7): 773-8.

[PMID: 8361047]

[10] Jayaratne P, Rutherford C. Detection of methicillin-resistant Staphylococcus aureus (MRSA) from growth on mannitol salt oxacillin agar using PCR for nosocomial surveillance. Diagn Microbiol Infect Dis 1999; 35(1): 13-8. [http://dx.doi.org/10.1016/S0732-8893(99)00060-7] [PMID: 10529876]

[11] Eigner U, Veldenzer A, Fahr AM, Holfelder M. Retrospective evaluation of a PCR based assay for the direct detection of methicillin-resistant Staphylococcus aureus in clinical specimen. Clin Lab 2012; 58(11-12): 1319-21.

[PMID: 23289206]

[12] Cuny C, Witte W. PCR for the identification of methicillin-resistant Staphylococcus aureus (MRSA) strains using a single primer pair specific for SCCmec elements and the neighbouring chromosome-borne orfX. Clin Microbiol Infect 2005; 11(10): 834-7. [http://dx.doi.org/10.1111/j.1469-0691.2005.01236.x] [PMID: 16153258]

[13] Chadwick SG, Prasad A, Smith WL, Mordechai E, Adelson ME, Gygax SE. Detection of epidemic USA300 community-associated methicillin-resistant Staphylococcus aureus strains by use of a single allele-specific PCR assay targeting a novel polymorphism of Staphylococcus aureus pbp3. J Clin Microbiol 2013; 51(8): 2541-50. [http://dx.doi.org/10.1128/JCM.00417-13] [PMID: 23698534]

[14] Stegger M, Lindsay JA, Moodley A, Skov R, Broens EM, Guardabassi L. Rapid PCR detection of Staphylococcus aureus clonal complex 398 by targeting the restriction-modification system carrying saul-hsdS1. J Clin Microbiol 2011; 49(2): 732-4. [http://dx.doi.org/10.1128/JCM.01970-10] [PMID: 21123532]

[15] Al-Talib H, Yean CY, Al-Khateeb A, Hasan H, Ravichandran M. Rapid detection of methicillin-resistant Staphylococcus aureus by a newly developed dry reagent-based polymerase chain reaction assay. J Microbiol Immunol Infect 2014; 47(6): 484-90. [http://dx.doi.org/10.1016/j.jmii.2013.06.004] [PMID: 23927820]

[16] Barski P, Piechowicz L, Galiński J, Kur J. Rapid assay for detection of methicillin-resistant Staphylococcus aureus using multiplex PCR. Mol Cell Probes 1996; 10(6): 471-5. [http://dx.doi.org/10.1006/mcpr.1996.0066] [PMID: 9025087]

[17] Brakstad OG, Maeland JA, Tveten Y. Multiplex polymerase chain reaction for detection of genes for Staphylococcus aureus thermonuclease and methicillin resistance and correlation with oxacillin resistance. APMIS 1993; 101(9): 681-8. [http://dx.doi.org/10.1111/j.1699-0463.1993.tb00165.x] [PMID: 8240787]

[18] Vannuffel P, Laterre PF, Bouyer M, et al. Rapid and specific molecular identification of methicillin-resistant Staphylococcus aureus in endotracheal aspirates from mechanically ventilated patients. J Clin Microbiol 1998; 36(8): 2366-8. [PMID: 9666026]

[19] Domann E, Hossain H, Füssle R, Chakraborty T. Rapid and reliable detection of multiresistent Staphylococcus aureus (MRSA) by multiplex PCR. Dtsch Med Wochenschr 2000; 125(20): 613-8. [http://dx.doi.org/10.1055/s-2007-1024385] [PMID: 11256043]

[20] Francois P, Pittet D, Bento M, et al. Rapid detection of methicillin-resistant Staphylococcus aureus directly from sterile or nonsterile clinical samples by a new molecular assay. J Clin Microbiol 2003; 41(1): 254-60. [http://dx.doi.org/10.1128/JCM.41.1.254-260.2003] [PMID: 12517857]

[21] Montazeri EA, Khosravi AD, Jolodar A, Ghaderpanah M, Azarpira S. Identification of methicillin-resistant Staphylococcus aureus (MRSA) strains isolated from burn patients by multiplex PCR. Burns 2015; 41(3): 590-4. [http://dx.doi.org/10.1016/j.burns.2014.08.018] [PMID: 25441547]

[22] García-Álvarez L, Holden MT, Lindsay H, et al. Meticillin-resistant Staphylococcus aureus with a novel mecA homologue in human and bovine populations in the UK and Denmark: a descriptive study. Lancet Infect Dis 2011; 11(8): 595-603. [http://dx.doi.org/10.1016/S1473-3099(11)70126-8] [PMID: 21641281]

[23] Becker K, Larsen AR, Skov RL, et al. Evaluation of a modular multiplex-PCR methicillin-resistant Staphylococcus aureus detection assay adapted for mecC detection. J Clin Microbiol 2013; 51(6): 1917-9. [http://dx.doi.org/10.1128/JCM.00075-13] [PMID: 23515551] 
[24] Pérez-Roth E, Claverie-Martín F, Villar J, Méndez-Alvarez S. Multiplex PCR for simultaneous identification of Staphylococcus aureus and detection of methicillin and mupirocin resistance. J Clin Microbiol 2001; 39(11): 4037-41. [http://dx.doi.org/10.1128/JCM.39.11.4037-4041.2001] [PMID: 11682527]

[25] Zhang K, Sparling J, Chow BL, et al. New quadriplex PCR assay for detection of methicillin and mupirocin resistance and simultaneous discrimination of Staphylococcus aureus from coagulase-negative staphylococci. J Clin Microbiol 2004; $42(11)$ : $4947-55$. [http://dx.doi.org/10.1128/JCM.42.11.4947-4955.2004] [PMID: 15528678]

[26] Zhang K, McClure JA, Elsayed S, Louie T, Conly JM. Novel multiplex PCR assay for simultaneous identification of community-associated methicillin-resistant Staphylococcus aureus strains USA300 and USA400 and detection of mecA and Panton-Valentine leukocidin genes, with discrimination of Staphylococcus aureus from coagulase-negative staphylococci. J Clin Microbiol 2008; 46(3): $1118-22$. [http://dx.doi.org/10.1128/JCM.01309-07] [PMID: 18160447]

[27] Bonnstetter KK, Wolter DJ, Tenover FC, McDougal LK, Goering RV. Rapid multiplex PCR assay for identification of USA300 communityassociated methicillin-resistant Staphylococcus aureus isolates. J Clin Microbiol 2007; 45(1): 141-6. [http://dx.doi.org/10.1128/JCM.01228-06] [PMID: 17093011]

[28] Al-Talib H, Yean CY, Al-Khateeb A, et al. A pentaplex PCR assay for the rapid detection of methicillin-resistant Staphylococcus aureus and Panton-Valentine Leucocidin. BMC Microbiol 2009; 9: 113. [http://dx.doi.org/10.1186/1471-2180-9-113] [PMID: 19476638]

[29] Panda S, Kar S, Choudhury R, Sharma S, Singh DV. Development and evaluation of hexaplex PCR for rapid detection of methicillin, cadmium/zinc and antiseptic-resistant staphylococci, with simultaneous identification of PVL-positive and -negative Staphylococcus aureus and coagulase negative staphylococci. FEMS Microbiol Lett 2014; 352(1): 114-22. [http://dx.doi.org/10.1111/1574-6968.12383] [PMID: 24417390]

[30] Ghodousi A, Nomanpour B, Davoudi S, et al. Application of fnbA gene as new target for the species-specific and quantitative detection of Staphylococcus aureus directly from lower respiratory tract specimens by real time PCR. Indian J Pathol Microbiol 2012; 55(4): 490-5. [http://dx.doi.org/10.4103/0377-4929.107787] [PMID: 23455786]

[31] O’Neill E, Humphreys H, O'Gara JP. Carriage of both the fnbA and fnbB genes and growth at 37 degrees C promote FnBP-mediated biofilm development in meticillin-resistant Staphylococcus aureus clinical isolates. J Med Microbiol 2009; 58(Pt 4): $399-402$. [http://dx.doi.org/10.1099/jmm.0.005504-0] [PMID: 19273632]

[32] Oberdorfer K, Pohl S, Frey M, Heeg K, Wendt C. Evaluation of a single-locus real-time polymerase chain reaction as a screening test for specific detection of methicillin-resistant Staphylococcus aureus in ICU patients. Eur J Clin Microbiol Infect Dis 2006; 25(10): 657-63. [http://dx.doi.org/10.1007/s10096-006-0203-2] [PMID: 17024506]

[33] Mehta MS, Paule SM, Hacek DM, Thomson RB, Kaul KL, Peterson LR. Optimization of a laboratory-developed test utilizing roche analytespecific reagents for detection of Staphylococcus aureus, methicillin-resistant S. aureus, and vancomycin-resistant Enterococcus species. J Clin Microbiol 2008; 46(7): 2377-80. [http://dx.doi.org/10.1128/JCM.00230-08] [PMID: 18448688]

[34] Huletsky A, Lebel P, Picard FJ, et al. Identification of methicillin-resistant Staphylococcus aureus carriage in less than 1 hour during a hospital surveillance program. Clin Infect Dis 2005; 40(7): 976-81. [http://dx.doi.org/10.1086/428579] [PMID: 15824989]

[35] Hagen RM, Seegmüller I, Navai J, Kappstein I, Lehn N, Miethke T. Development of a real-time PCR assay for rapid identification of methicillin-resistant Staphylococcus aureus from clinical samples. Int J Med Microbiol 2005; 295(2): 77-86 [http://dx.doi.org/10.1016/j.ijmm.2004.12.008] [PMID: 15969468]

[36] Danial J, Noel M, Templeton KE, et al. Real-time evaluation of an optimized real-time PCR assay versus Brilliance chromogenic MRSA agar for the detection of meticillin-resistant Staphylococcus aureus from clinical specimens. J Med Microbiol 2011; 60(Pt 3): 323-8. [http://dx.doi.org/10.1099/jmm.0.025288-0] [PMID: 21109629]

[37] Stratidis J, Bia FJ, Edberg SC. Use of real-time polymerase chain reaction for identification of methicillin-resistant Staphylococcus aureus directly from positive blood culture bottles. Diagn Microbiol Infect Dis 2007; 58(2): 199-202. [http://dx.doi.org/10.1016/j.diagmicrobio.2006.12.017] [PMID: 17368796]

[38] Wellinghausen N, Siegel D, Gebert S, Winter J. Rapid detection of Staphylococcus aureus bacteremia and methicillin resistance by real-time PCR in whole blood samples. Eur J Clin Microbiol Infect Dis 2009; 28(8): 1001-5. [http://dx.doi.org/10.1007/s10096-009-0723-7] [PMID: 19277734]

[39] Tan TY, Corden S, Barnes R, Cookson B. Rapid identification of methicillin-resistant Staphylococcus aureus from positive blood cultures by real-time fluorescence PCR. J Clin Microbiol 2001; 39(12): 4529-31. [http://dx.doi.org/10.1128/JCM.39.12.4529-4531.2001] [PMID: 11724876]

[40] Warren DK, Liao RS, Merz LR, Eveland M, Dunne WM Jr. Detection of methicillin-resistant Staphylococcus aureus directly from nasal swab specimens by a real-time PCR assay. J Clin Microbiol 2004; 42(12): 5578-81. [http://dx.doi.org/10.1128/JCM.42.12.5578-5581.2004] [PMID: 15583284]

[41] Desjardins M, Guibord C, Lalonde B, Toye B, Ramotar K. Evaluation of the IDI-MRSA assay for detection of methicillin-resistant Staphylococcus aureus from nasal and rectal specimens pooled in a selective broth. J Clin Microbiol 2006; 44(4): 1219-23. [http://dx.doi.org/10.1128/JCM.44.4.1219-1223.2006] [PMID: 16597841] 
[42] Hogg GM, McKenna JP, Ong G. Rapid detection of methicillin-susceptible and methicillin-resistant Staphylococcus aureus directly from positive BacT/Alert blood culture bottles using real-time polymerase chain reaction: evaluation and comparison of 4 DNA extraction methods. Diagn Microbiol Infect Dis 2008; 61(4): 446-52.

[http://dx.doi.org/10.1016/j.diagmicrobio.2008.03.012] [PMID: 18501547]

[43] Sabet NS, Subramaniam G, Navaratnam P, Sekaran SD. Detection of mecA and ermA genes and simultaneous identification of Staphylococcus aureus using triplex real-time PCR from Malaysian S. aureus strain collections. Int J Antimicrob Agents 2007; 29(5): 582-5. [http://dx.doi.org/10.1016/j.ijantimicag.2006.12.017] [PMID: 17314034]

[44] Huletsky A, Giroux R, Rossbach V, et al. New real-time PCR assay for rapid detection of methicillin-resistant Staphylococcus aureus directly from specimens containing a mixture of staphylococci. J Clin Microbiol 2004; 42(5): 1875-84. [http://dx.doi.org/10.1128/JCM.42.5.1875-1884.2004] [PMID: 15131143]

[45] Söderquist B, Neander M, Dienus O, et al. Real-time multiplex PCR for direct detection of methicillin-resistant Staphylococcus aureus (MRSA) in clinical samples enriched by broth culture. APMIS 2012; 120(5): 427-32. [http://dx.doi.org/10.1111/j.1600-0463.2011.02849.x] [PMID: 22515298]

[46] Kim JU, Cha CH, An HK, Lee HJ, Kim MN. Multiplex real-time PCR assay for detection of methicillin-resistant Staphylococcus aureus (MRSA) strains suitable in regions of high MRSA endemicity. J Clin Microbiol 2013; 51(3): 1008-13. [http://dx.doi.org/10.1128/JCM.02495-12] [PMID: 23269729]

[47] Sabet NS, Subramaniam G, Navaratnam P, Sekaran SD. Simultaneous species identification and detection of methicillin resistance in staphylococci using triplex real-time PCR assay. Diagn Microbiol Infect Dis 2006; 56(1): 13-8. [http://dx.doi.org/10.1016/j.diagmicrobio.2006.02.013] [PMID: 16650954]

[48] Renwick L, Hardie A, Girvan EK, et al. Detection of meticillin-resistant Staphylococcus aureus and Panton-Valentine leukocidin directly from clinical samples and the development of a multiplex assay using real-time polymerase chain reaction. Eur J Clin Microbiol Infect Dis 2008; 27(9): 791-6. [http://dx.doi.org/10.1007/s10096-008-0503-9] [PMID: 18357477]

[49] Fosheim GE, Nicholson AC, Albrecht VS, Limbago BM. Multiplex real-time PCR assay for detection of methicillin-resistant Staphylococcus aureus and associated toxin genes. J Clin Microbiol 2011; 49(8): 3071-3. [http://dx.doi.org/10.1128/JCM.00795-11] [PMID: 21697325]

[50] Yadav MK, Kwon SK, Huh HJ, Chae SW, Song JJ. Detection of methicillin-resistant Staphylococcus aureus (MRSA) from nasal samples by multiplex real-time PCR based on dual priming AT-rich primers. Folia Microbiol (Praha) 2012; 57(1): 37-45. [http://dx.doi.org/10.1007/s12223-011-0085-2] [PMID: 22187362]

[51] Kilic A, Muldrew KL, Tang YW, Basustaoglu AC. Triplex real-time polymerase chain reaction assay for simultaneous detection of Staphylococcus aureus and coagulase-negative staphylococci and determination of methicillin resistance directly from positive blood culture bottles. Diagn Microbiol Infect Dis 2010; 66(4): 349-55. [http://dx.doi.org/10.1016/j.diagmicrobio.2009.11.010] [PMID: 20226325]

[52] Kilic A, Basustaoglu AC. Double triplex real-time PCR assay for simultaneous detection of Staphylococcus aureus, Staphylococcus epidermidis, Staphylococcus hominis, and Staphylococcus haemolyticus and determination of their methicillin resistance directly from positive blood culture bottles. Res Microbiol 2011; 162(10): 1060-6. [http://dx.doi.org/10.1016/j.resmic.2011.07.009] [PMID: 21925597]

[53] Oh AC, Lee JK, Lee HN, et al. Clinical utility of the Xpert MRSA assay for early detection of methicillin-resistant Staphylococcus aureus. Mol Med Rep 2013; 7(1): 11-5. [PMID: 23064681]

[54] Kelley PG, Grabsch EA, Farrell J, et al. Evaluation of the Xpert ${ }^{\mathrm{TM}}$ MRSA/SA Blood Culture assay for the detection of Staphylococcus aureus including strains with reduced vancomycin susceptibility from blood culture specimens. Diagn Microbiol Infect Dis 2011; 70(3): 404-7. [http://dx.doi.org/10.1016/j.diagmicrobio.2011.02.006] [PMID: 21497042]

[55] Laurent C, Bogaerts P, Schoevaerdts D, et al. Evaluation of the Xpert MRSA assay for rapid detection of methicillin-resistant Staphylococcus aureus from nares swabs of geriatric hospitalized patients and failure to detect a specific SCCmec type IV variant. Eur J Clin Microbiol Infect Dis 2010; 29(8): 995-1002. [http://dx.doi.org/10.1007/s10096-010-0958-3] [PMID: 20512518]

[56] Patel PA, Schora DM, Peterson KE, Grayes A, Boehm S, Peterson LR. Performance of the Cepheid Xpert ${ }^{\circledR}$ SA Nasal Complete PCR assay compared to culture for detection of methicillin-sensitive and methicillin-resistant Staphylococcus aureus colonization. Diagn Microbiol Infect Dis 2014; 80(1): 32-4. [http://dx.doi.org/10.1016/j.diagmicrobio.2014.05.019] [PMID: 24952987]

[57] Valour F, Blanc-Pattin V, Freydière AM, et al. Rapid detection of Staphylococcus aureus and methicillin resistance in bone and joint infection samples: evaluation of the GeneXpert MRSA/SA SSTI assay. Diagn Microbiol Infect Dis 2014; 78(3): 313-5. [http://dx.doi.org/10.1016/j.diagmicrobio.2013.11.026] [PMID: 24374309]

[58] Cercenado E, Marín M, Burillo A, Martín-Rabadán P, Rivera M, Bouza E. Rapid detection of Staphylococcus aureus in lower respiratory tract secretions from patients with suspected ventilator-associated pneumonia: evaluation of the Cepheid Xpert MRSA/SA SSTI assay. J Clin Microbiol 2012; 50(12): 4095-7.

[http://dx.doi.org/10.1128/JCM.02409-12] [PMID: 22993185] 
[59] Rossney AS, Herra CM, Brennan GI, Morgan PM, O’Connell B. Evaluation of the Xpert methicillin-resistant Staphylococcus aureus (MRSA) assay using the GeneXpert real-time PCR platform for rapid detection of MRSA from screening specimens. J Clin Microbiol 2008; 46(10): 3285-90.

[http://dx.doi.org/10.1128/JCM.02487-07] [PMID: 18685003]

[60] Wolk DM, Picton E, Johnson D, et al. Multicenter evaluation of the Cepheid Xpert methicillin-resistant Staphylococcus aureus (MRSA) test as a rapid screening method for detection of MRSA in nares. J Clin Microbiol 2009; 47(3): 758-64. [http://dx.doi.org/10.1128/JCM.01714-08] [PMID: 19129414]

[61] Ghebremedhin B, König B, König W. BD GeneOhm-MRSA assay for detection of methicillin-resistant Staphylococcus aureus directly in nasal and non-nasal swab specimens from haematologic patients. Eur J Microbiol Immunol (Bp) 2011; 1(4): $297-301$. [http://dx.doi.org/10.1556/EuJMI.1.2011.4.5] [PMID: 24516736]

[62] Lucke K, Hombach M, Hug M, Pfyffer GE. Rapid detection of methicillin-resistant Staphylococcus aureus (MRSA) in diverse clinical specimens by the BD GeneOhm MRSA assay and comparison with culture. J Clin Microbiol 2010; 48(3): 981-4. [http://dx.doi.org/10.1128/JCM.01990-09] [PMID: 20071545]

[63] Hirvonen JJ, von Lode P, Nevalainen M, Rantakokko-Jalava K, Kaukoranta SS. One-step sample preparation of positive blood cultures for the direct detection of methicillin-sensitive and resistant Staphylococcus aureus and methicillin-resistant coagulase-negative staphylococci within one hour using the automated GenomEra CDXTM PCR system. Eur J Clin Microbiol Infect Dis 2012; 31(10): $2835-42$. [http://dx.doi.org/10.1007/s10096-012-1637-3] [PMID: 22639174]

[64] Yam WC, Siu GK, Ho PL, et al. Evaluation of the LightCycler methicillin-resistant Staphylococcus aureus (MRSA) advanced test for detection of MRSA nasal colonization. J Clin Microbiol 2013; 51(9): 2869-74. [http://dx.doi.org/10.1128/JCM.00488-13] [PMID: 23784133]

[65] Arcenas RC, Spadoni S, Mohammad A, et al. Multicenter evaluation of the LightCycler MRSA advanced test, the Xpert MRSA Assay, and MRSASelect directly plated culture with simulated workflow comparison for the detection of methicillin-resistant Staphylococcus aureus in nasal swabs. J Mol Diagn 2012; 14(4): 367-75.

[http://dx.doi.org/10.1016/j.jmoldx.2012.01.015] [PMID: 22584139]

[66] Gill P, Ghaemi A. Nucleic acid isothermal amplification technologies: a review. Nucleosides Nucleotides Nucleic Acids 2008; 27(3): 224-43. [http://dx.doi.org/10.1080/15257770701845204] [PMID: 18260008]

[67] Goldmeyer J, Li H, McCormac M, et al. Identification of Staphylococcus aureus and determination of methicillin resistance directly from positive blood cultures by isothermal amplification and a disposable detection device. J Clin Microbiol 2008; 46(4): 1534-6. [http://dx.doi.org/10.1128/JCM.02234-07] [PMID: 18234878]

[68] Frech GC, Munns D, Jenison RD, Hicke BJ. Direct detection of nasal Staphylococcus aureus carriage via helicase-dependent isothermal amplification and chip hybridization. BMC Res Notes 2012; 5: 430. [http://dx.doi.org/10.1186/1756-0500-5-430] [PMID: 22882800]

[69] Notomi T, Okayama H, Masubuchi H, et al. Loop-mediated isothermal amplification of DNA. Nucleic Acids Res 2000; $28(12)$ : E63. [http://dx.doi.org/10.1093/nar/28.12.e63] [PMID: 10871386]

[70] Misawa Y, Yoshida A, Saito R, et al. Application of loop-mediated isothermal amplification technique to rapid and direct detection of methicillin-resistant Staphylococcus aureus (MRSA) in blood cultures. J Infect Chemother 2007; 13(3): 134-40. [http://dx.doi.org/10.1007/s10156-007-0508-9] [PMID: 17593498]

[71] Wang XR, Wu LF, Wang Y, Ma YY, Chen FH, Ou HL. Rapid detection of Staphylococcus aureus by loop-mediated isothermal amplification. Appl Biochem Biotechnol 2015; 175(2): 882-91. [http://dx.doi.org/10.1007/s12010-014-1328-x] [PMID: 25349088]

[72] Su J, Liu X, Cui H, et al. Rapid and simple detection of methicillin-resistance Staphylococcus aureus by orfX loop-mediated isothermal amplification assay. BMC Biotechnol 2014; 14: 8. [http://dx.doi.org/10.1186/1472-6750-14-8] [PMID: 24456841]

[73] Zhao X, Li Y, Park M, et al. Loop-mediated isothermal amplification assay targeting the femA gene for rapid detection of Staphylococcus aureus from clinical and food samples. J Microbiol Biotechnol 2013; 23(2): 246-50. [http://dx.doi.org/10.4014/jmb.1207.07022] [PMID: 23412068]

[74] Hanaki K, Sekiguchi J, Shimada K, et al. Loop-mediated isothermal amplification assays for identification of antiseptic and methicillinresistant Staphylococcus aureus. J Microbiol Methods 2011; 84(2): 251-4. [http://dx.doi.org/10.1016/j.mimet.2010.12.004] [PMID: 21167878]

[75] Chan WS, Tang BS, Boost MV, Chow C, Leung PH. Detection of methicillin-resistant Staphylococcus aureus using a gold nanoparticle-based colourimetric polymerase chain reaction assay. Biosens Bioelectron 2014; 53: 105-11. [http://dx.doi.org/10.1016/j.bios.2013.09.027] [PMID: 24125759]

[76] Towner KJ, Talbot DC, Curran R, Webster CA, Humphreys H. Development and evaluation of a PCR-based immunoassay for the rapid detection of methicillin-resistant Staphylococcus aureus. J Med Microbiol 1998; 47(7): 607-13. [http://dx.doi.org/10.1099/00222615-47-7-607] [PMID: 9839565]

[77] Vannuffel P, Gigi J, Ezzedine H, et al. Specific detection of methicillin-resistant Staphylococcus species by multiplex PCR. J Clin Microbiol 1995; 33(11): 2864-7. [PMID: 8576335] 
[78] Schuenck RP, Lourenco MC, Iório NL, Ferreira AL, Nouér SA, Santos KR. Improved and rapid detection of methicillin-resistant Staphylococcus aureus nasal carriage using selective broth and multiplex PCR. Res Microbiol 2006; 157(10): 971-5. [http://dx.doi.org/10.1016/j.resmic.2006.08.004] [PMID: 17005377]

[79] Francis ST, Rawal S, Roberts H, Riley P, Planche T, Kennea NL. Detection of meticillin-resistant Staphylococcus aureus (MRSA) colonization in newborn infants using real-time polymerase chain reaction (PCR). Acta Paediatr 2010; 99(11): 1691-4. [http://dx.doi.org/10.1111/j.1651-2227.2010.01899.x] [PMID: 20528798]

[80] Fang H, Hedin G. Rapid screening and identification of methicillin-resistant Staphylococcus aureus from clinical samples by selective-broth and real-time PCR assay. J Clin Microbiol 2003; 41(7): 2894-9. [http://dx.doi.org/10.1128/JCM.41.7.2894-2899.2003] [PMID: 12843018]

[81] Johnson JA, Wright ME, Sheperd LA, Musher DM, Dang BN. Nasal methicillin-resistant Staphylococcus aureus polymerase chain reaction: a potential use in guiding antibiotic therapy for pneumonia. Perm J 2015; 19(1): 34-6. [http://dx.doi.org/10.7812/TPP/14-101] [PMID: 25432002]

[82] Kerremans JJ, Maaskant J, Verbrugh HA, van Leeuwen WB, Vos MC. Detection of methicillin-resistant Staphylococcus aureus in a lowprevalence setting by polymerase chain reaction with a selective enrichment broth. Diagn Microbiol Infect Dis 2008; 61(4): 396-401. [http://dx.doi.org/10.1016/j.diagmicrobio.2008.04.004] [PMID: 18501551]

[83] Grisold AJ, Leitner E, Mühlbauer G, Marth E, Kessler HH. Detection of methicillin-resistant Staphylococcus aureus and simultaneous confirmation by automated nucleic acid extraction and real-time PCR. J Clin Microbiol 2002; 40(7): 2392-7. [http://dx.doi.org/10.1128/JCM.40.7.2392-2397.2002] [PMID: 12089253]

[84] Kim MH, Lee WI, Kang SY. Detection of methicillin-resistant Staphylococcus aureus in healthcare workers using real-time polymerase chain reaction. Yonsei Med J 2013; 54(5): 1282-4. [http://dx.doi.org/10.3349/ymj.2013.54.5.1282] [PMID: 23918582]

[85] Fodrie TY, Allen SD, Blue DE, Gary P, Cheng L. Evaluation of a real-time polymerase chain reaction assay using analyte-specific reagents for detection of methicillin-resistant Staphylococcus aureus nasal carriage. Anal Quant Cytol Histol 2009; 31(6): 410-6. [PMID: 20698357]

[86] Creamer E, Dolan A, Sherlock O, et al. The effect of rapid screening for methicillin-resistant Staphylococcus aureus (MRSA) on the identification and earlier isolation of MRSA-positive patients. Infect Control Hosp Epidemiol 2010; 31(4): $374-81$. [http://dx.doi.org/10.1086/651093] [PMID: 20184438]

[87] Oberdorfer K, Pohl S, Frey M, Heeg K, Wendt C. Evaluation of a single-locus real-time polymerase chain reaction as a screening test for specific detection of methicillin-resistant Staphylococcus aureus in ICU patients. Eur J Clin Microbiol Infect Dis 2006; 25(10): 657-63. [http://dx.doi.org/10.1007/s10096-006-0203-2] [PMID: 17024506]

[88] Shrestha NK, Tuohy MJ, Hall GS, Isada CM, Procop GW. Rapid identification of Staphylococcus aureus and the mecA gene from BacT/ALERT blood culture bottles by using the LightCycler system. J Clin Microbiol 2002; 40(7): $2659-61$. [http://dx.doi.org/10.1128/JCM.40.7.2659-2661.2002] [PMID: 12089301]

[89] Levi K, Towner KJ. Rapid detection of methicillin-resistant Staphylococcus aureus from screening enrichment broths by real-time PCR. Eur J Clin Microbiol Infect Dis 2005; 24(6): 423-7. [http://dx.doi.org/10.1007/s10096-005-1336-4] [PMID: 15926061]

[90] Peterson LR, Liesenfeld O, Woods CW, et al. Multicenter evaluation of the LightCycler methicillin-resistant Staphylococcus aureus (MRSA) advanced test as a rapid method for detection of MRSA in nasal surveillance swabs. J Clin Microbiol 2010; 48(5): 1661-6. [http://dx.doi.org/10.1128/JCM.00003-10] [PMID: 20335423]

[91] Reischl U, Linde HJ, Metz M, Leppmeier B, Lehn N. Rapid identification of methicillin-resistant Staphylococcus aureus and simultaneous species confirmation using real-time fluorescence PCR. J Clin Microbiol 2000; 38(6): 2429-33. [PMID: 10835024]

[92] Lim KT, Teh CS, Thong KL. Loop-mediated Isothermal amplifcation assay for the rapid Detection of Staphylococcus aureus. Biomed Res Int $2013 ; 2013$

[93] Levi K, Bailey C, Bennett A, Marsh P, Cardy DL, Towner KJ. Evaluation of an isothermal signal amplification method for rapid detection of methicillin-resistant Staphylococcus aureus from patient-screening swabs. J Clin Microbiol 2003; 41(7): $3187-91$. [http://dx.doi.org/10.1128/JCM.41.7.3187-3191.2003] [PMID: 12843062]

\begin{tabular}{ll}
\hline Received: July 13, 2015 & Revised: January 3, $2016 \quad$ Accepted: January 9, 2016 \\
C Liu et al.; Licensee Bentham Open. &
\end{tabular}

This is an open access article licensed under the terms of the Creative Commons Attribution-Non-Commercial 4.0 International Public License (CC BY-NC 4.0) (https://creativecommons.org/licenses/by-nc/4.0/legalcode), which permits unrestricted, non-commercial use, distribution and reproduction in any medium, provided the work is properly cited. 